\title{
Hypothalamic Lipids and the Regulation of Energy Homeostasis
}

\author{
Carlos Diéguez ${ }^{\mathrm{a}, \mathrm{b}} \quad$ Gema Frühbeck $^{\mathrm{b}, \mathrm{c}} \quad$ Miguel López $^{\mathrm{a}, \mathrm{b}}$ \\ a Department of Physiology, School of Medicine, University of Santiago de Compostela,

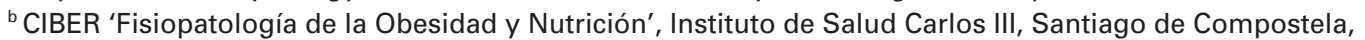 \\ c Metabolic Research Laboratory, Clínica Universitaria de Navarra, University of Navarra, Pamplona, Spain
}

\section{Key Words}

AMP-activated protein kinase - Acetyl-CoA carboxylase . Fatty acid synthase - Food intake - Hypothalamus . Lipid sensing

\section{Summary}

The hypothalamus is a specialised area in the brain that integrates the control of energy homeostasis, regulating both food intake and energy expenditure. The classical theory for hypothalamic feeding control is mainly based on the relationship between peripheral signals and neurotransmitters/neuromodulators in the central nervous system. Thus, hypothalamic neurons respond to peripheral signals, such as hormones and nutrients, by modifying the synthesis of neuropeptides. Despite the well-established role of these hypothalamic networks, increasing evidence indicates that the modulation of lipid metabolism in the hypothalamus plays a critical role in feeding control. In fact, the pharmacologic and genetic targeting of key enzymes from these pathways, such as AMP-activated protein kinase, acetyl-CoA carboxylase, carnitine palmitoyltransferase 1, fatty acid synthase, and malonyl-CoA decarboxylase, has a profound effect on food intake and body weight. Here, we review what is currently known about the relationship between hypothalamic lipid metabolism and whole body energy homeostasis. Defining these novel mechanisms may offer new therapeutic targets for the treatment of obesity and its associated pathologies.

\section{Introduction}

Obesity is characterised by excess fat accumulation in the adipose tissue, which causes adverse health problems [1-4]. Currently, the degree of obesity and its related disorders are increasing at a pandemic rate. For this reason, much research effort is concentrated on recognising the molecular mechanisms governing energy balance and food intake.

The central nervous system (CNS) senses the sensory experience of eating as well as the process of ingestion, absorption, metabolism and energy storage. The original theories describing the central control of food intake were based on a 'Dual Centre Hypothesis' [5, 6]. In this model, originated from hypothalamic lesioning experiments, feeding was controlled by 2 main hypothalamic areas: the lateral hypothalamic area (LHA) representing the 'feeding centres' as opposed to the ventromedial hypothalamic nucleus (VMH) embodying the 'satiety centres'. Lesions of the LHA reduced food intake and eventually lead to starvation and death. Contrarily, lesions of the VMH resulted in obesity. In spite of our increasing understanding of the hypothalamic regulation of feeding, the main idea remains indisputable, i.e. that anatomically defined hypothalamic areas regulate food intake. These hypothalamic nuclei form interconnected neuronal circuits which react to changes in energy status by altering the expression of specific neuropeptides, resulting in changes in energy intake and expenditure [7-10]. Among them, the arcuate nucleus of the hypothalamus (ARC) is considered as the 'master hypothalamic centre' for food intake control. Two distinct neuronal populations in the ARC integrate peripheral nutritional/feeding signals. One set of neurons expresses the orexigenic (feeding-promoting) neuropeptides agouti-related protein (AgRP) and neuropeptide Y (NPY). These neurons project and modulate downstream 'second order' neurons located in other hypothalamic nuclei, such as the paraventricular nucleus (PVH)

\begin{tabular}{ll}
\hline KARGER & $\oplus$ 2009 S. Karger GmbH, Freiburg \\
Fax +497614520714 & Accessible online at: \\
$\begin{array}{l}\text { Information@Karger.de } \\
\text { www.karger.com }\end{array}$ & www.karger.com/ofa
\end{tabular}

Miguel López, PhD

Department of Physiology, School of Medicine

University of Santiago de Compostela

S. Francisco s/n 15782, Santiago de Compostela (A Coruña), Spain

Tel. +34 981-582658, Fax -574145

m.lopez@usc.es 
Fig. 1. Fatty acid synthesis pathway: Excess glucose in the cell is first converted to pyruvate via glycolysis in the cytoplasm. Pyruvate enters the mitochondria and is converted to acetyl-CoA and transported as citrate from mitochondria to the cytoplasm. ATP citrate lyase (ACL) then reconverts citrate to acetyl-CoA. Acetyl-CoA carboxylase (ACC) catalyses the carboxylation of acetyl-CoA to malonyl-CoA. Both acetyl-CoA and malonyl-CoA are then used as the substrates for the production of palmitate catalysed by fatty acid synthase (FAS). Malonyl-CoA decarboxylase (MCD) converts malonyl-CoA back to acetyl-CoA. Carnitine palmitoyltransferase 1 (CPT1) is the enzyme importing long-chain fatty acyl-CoA into mitochondria for $\beta$-oxidation; CPT1 activity is allosterically inhibited by malonyl-CoA. The resulting saturated fatty acid molecule produced by FAS can be further metabolised depending on requirements, desaturated to form unsaturated fatty acids, derived to triglyceride molecules, or channelled to a range of phospholipids and derivatives for membrane and signalling functions.

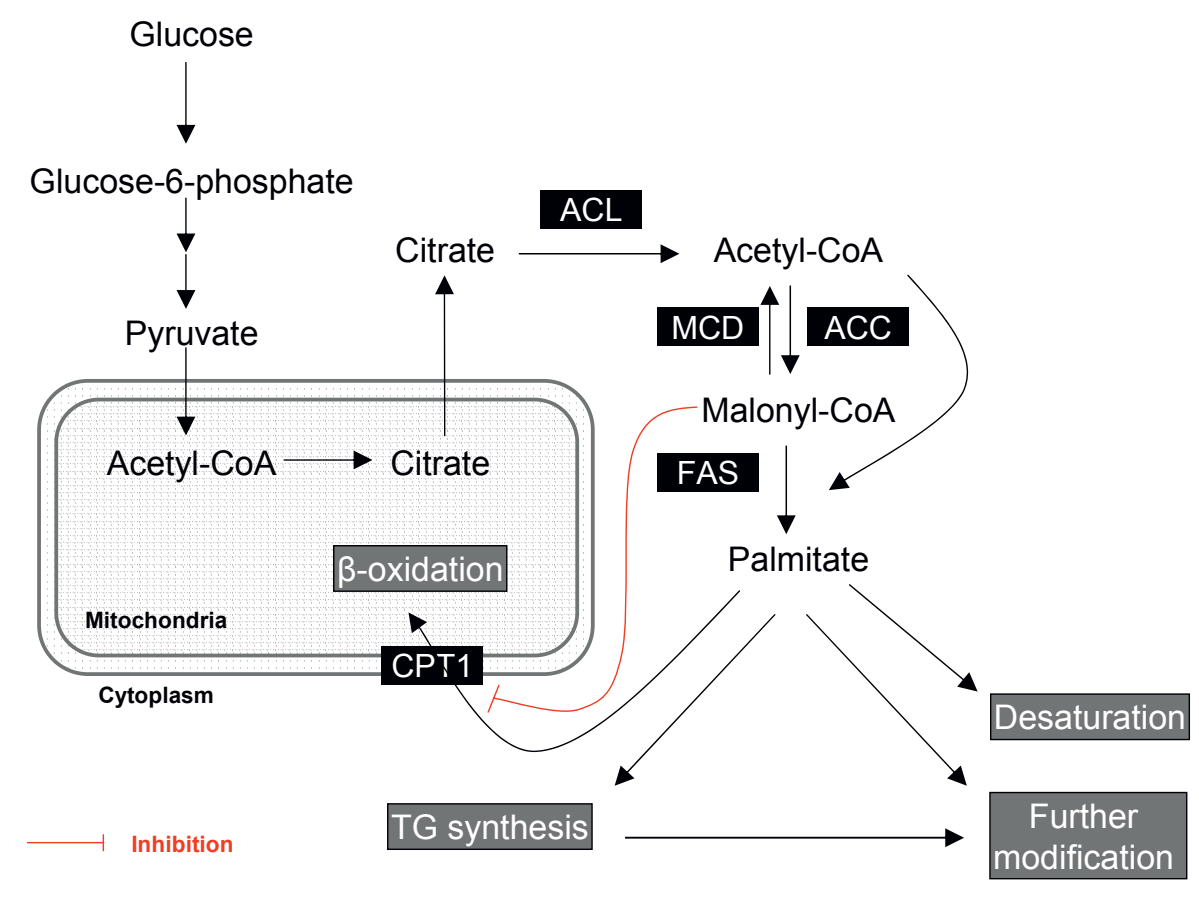

[11]. A second set of ARC neurons expresses the anorexigenic (feeding inhibitors) products of proopiomelanocortin (POMC), the precursor of alpha-melanocyte-stimulating hormone $(\alpha-\mathrm{MSH})$, and the cocaine and amphetamine-regulated transcript (CART). This population of neurons projects more broadly within the CNS, to secondary hypothalamic nuclei such as the dorsomedial nucleus (DMH), the LHA, and the perifornical area (PFA), in addition to the PVH. Dorsal to the ARC lays the VMH which receives projections from AgRP/ NPY and CART/POMC neurons in the ARC [12-18]. Additionally, the $\mathrm{VMH}$ neurons project their axons to the ARC, $\mathrm{DMH}, \mathrm{LHA}$ as well as brain-stem regions, such as the nucleus of the solitary tract (NTS). Hypothalamic neurons respond to peripheral signals, such as glucose, leptin, ghrelin, adiponectin (Adpn), resistin (RSTN), and insulin, by modifying the expression of key neuropeptides, especially in the ARC but also in other nuclei such as PVH and LHA [7-10, 19-27]. When energy intake exceeds expenditure, the expression of orexigenic neuropeptides, such as AgRP and NPY diminishes, whereas the expression of anorexigenic neuropeptides, such as CART and POMC, rises. Opposite changes occur when energy expenditure exceeds intake [7-10]. Besides the ARC, LHA, and PVH current, evidence has identified the VMH as a key nucleus integrating peripheral signals, such as ghrelin [28, 29] and RSTN [27].

During the last 8 years, a bulk of data has demonstrated that in addition to nutrients, hormones, and neuropeptides, basic cellular metabolic pathways play a major role in the regulation of whole body energy homeostasis. The present review summarises the current knowledge about hypothalamic lipid metabolism and energy homeostasis.

\section{Fatty Acid Metabolism Pathway}

Fatty acids are derived either from the diet or by de novo synthesis. The basic pathway for de novo fatty acid synthesis is summarised in figure 1 [30-32]. The de novo fatty acid biosynthesis pathway comprises 3 key enzymes, acetyl-CoA carboxylase (ACC; EC 6.4.1.2), fatty acid synthase (FAS; EC 2.3.1.85), and malonyl-CoA decarboxylase (MCD; EC 4.1.1.9). ACC catalyses the carboxylation of acetyl-CoA to malonyl-CoA in an ATP-dependent manner. The synthesis step of malonyl-CoA is reversibly regulated by MCD that converts malonyl-CoA back to acetyl-CoA. Both acetyl-CoA and malonyl-CoA are then used as the substrates for the production of palmitate (C16:0), the major product of FAS. The synthesis of palmitate is achieved by the sequential condensation of 7 malonyl-CoA moieties onto a growing carbon chain founded from an acetyl group from acetyl-CoA. The resulting saturated fatty acid molecule produced by FAS can be further metabolised depending on requirements; desaturated to form unsaturated fatty acids, derived to triglyceride molecules for storage, or channelled to a range of phospholipids and derivatives for membrane and signalling functions [30-32].

Malonyl-CoA is an intermediary product in the biosynthesis of fatty acids but also an important regulator of the balance between de novo lipogenesis and fatty acid oxidation. Levels of malonyl-CoA depend on the equilibrium between ACC, FAS, and MCD activities. The activities of ACC and MCD are regulated by phosphorylation via AMP-activated protein kinase (AMPK). Activated (phosphorylated) AMPK phosphorylates and inhibits ACC, whilst activating MCD 
Fig. 2. Hypothalamic fatty acid metabolism integrates peripheral signals with neuropeptide systems: Peripheral hormonal and nutrient/metabolic signals operate on the different components of the fatty acid metabolic pathway, modulating the cytoplasmatic pool of malonyl-CoA and palmitoyl-CoA. This effect elicits changes in neuropeptide expression, such as agouti-related protein (AgRP), neuropeptide Y (NPY), cocaine and amphetamine-regulated transcript (CART), and proopiomelanocortin (POMC) by still undefined mechanisms (represented as ?) which ultimately regulates feeding. In addition, current

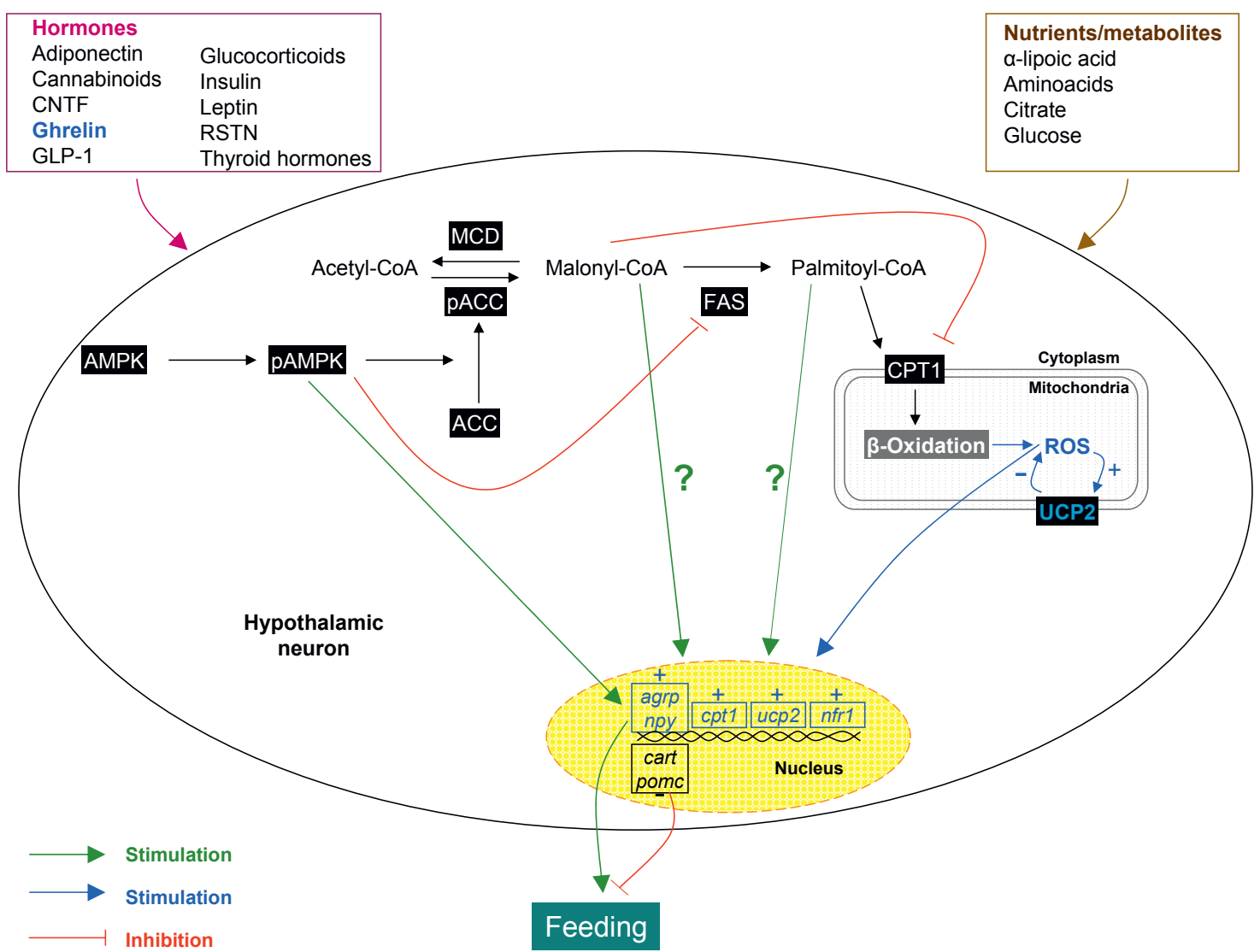
evidence has demonstrated that ghrelin-induced carnitine palmitoyltransferase 1 (CPT1) activation promotes the generation of reactive oxygen species (ROS). Fatty acids and ROS increase uncoupling protein 2(UCP2)-dependent uncoupling activity and UCP2 gene expression which subsequently decreases ROS in a feedback manner, allowing appropriate ghrelin-induced gene transcription. Further work is necessary to demonstrate whether this mechanism (labelled in blue), besides ghrelin, is extensive to other peripheral signals modulating food intake. NrF1 = Nuclear respiratory factor 1 .

[30-32, 33]. In addition, activated AMPK decreases FAS mRNA expression via a sterol regulatory element binding protein-1(SREBP-1)-dependent mechanism [28, 29, 34]. Thus, the overall effect of AMPK activation is reducing malonyl$\mathrm{CoA}$ and the flux of substrates in the fatty acid biosynthetic pathway. Decreased malonyl-CoA levels stimulate carnitine palmitoyltransferase 1 (CPT1), the enzyme importing longchain fatty acyl-CoA (LCFAs-CoA) into mitochondria for their $\beta$-oxidation. Thus, altering the flux through the pathway, levels of malonyl-CoA can be regulated to activate or inhibit mitochondrial $\beta$-oxidation [30-32]. The metabolic significance of malonyl-CoA levels is emphasised by the fact that there are 2 isoforms of ACC, ACC1 and ACC2, both of which catalyse formation of malonyl-CoA [30-32, 35]. ACC1 is expressed mainly in lipogenic tissues, e.g. liver and adipose tissue, where it carries out the first step in fatty acid biosynthesis. Certain tissues, such as skeletal and heart muscle, do not carry out a significant amount of fatty acid synthesis due to low levels of FAS. In these tissues, ACC2 synthesises malonyl-CoA for modulation of CPT1 activity instead of biosynthetic purposes $[30-32,35]$.

\section{Hypothalamic Fatty Acid Metabolism Modulates Feeding: The 'Malonyl-CoA Hypothesis'}

Fatty acid biosynthetic enzymes are constitutively expressed in the brain. Neurons and glial cells need lipid synthesis to maintain their metabolic homeostasis. Importantly, ACC, AMPK, CPT1, FAS, and MCD mRNAs and proteins are highly expressed in hypothalamic nuclei involved in energy homeostasis, such as ARC, DMH, PVH and VMH [28, 29, 36-41]. Despite the fact that anatomical evidence suggested that the fatty acid metabolism was important in hypothalamic neurons, the interest in the role of fatty acid metabolism in energy balance came from the field of oncology [42]. The finding that numerous tumours expressed high levels of FAS raised the possibility that inhibition of this enzyme could be a target for cancer treatment [42]. Interestingly, treatments with FAS inhibitors, such as cerulenin and C75, produced a massive weight loss, which was associated with a marked hypophagic effect [43]. It is noteworthy that the anorectic effect of these drugs, especially $\mathrm{C} 75$, is mediated by the accumulation of malonyl-CoA in the hypothalamus, which is sensed as a signal of nutrient abundance ('malonyl-CoA hypothesis') [44]. In fact, simultaneous 
inhibition of FAS and ACC (by 5-(tetradecyloxy)-2-furoic acid, TOFA) prevents malonyl-CoA accumulation and consequently does not result in decreased food consumption [39, 43, 44]. Conversely, reduction of malonyl-CoA levels by adeno-associated, virus-mediated gene transfer of MCD into the medial basal hypothalamus of rats results in increased food intake and progressive weight gain $[45,46]$.

The anorectic effect of FAS inhibitors is associated with decreased expression of orexigenic (AgRP and NPY) and elevated expression of anorexigenic (CART, POMC) neuropeptides in the ARC (fig. 2) [43, 47]. Although the molecular mechanisms of the actions of FAS inhibitors on neuropeptides are not fully understood, two possible mechanisms have been proposed. Firstly, malonyl-CoA or a derivative can interact directly with a signalling protein that regulates the expression of neuropeptides. Supporting this idea is the evidence that malonyl-CoA can act directly as a signalling molecule in bacteria. The FapR (also known as FabR) transcription factor in Bacillus subtilis modulates the expression of several genes involved in fatty acid metabolism [48]. Secondly, malonyl-CoA can act indirectly by inhibiting CPT1 and prevent access of LCFAsCoA into the mitochondria. Accumulation of cytoplasmic fatty acyl-CoA thus could interact with signalling proteins that regulate expression of the orexigenic and anorexigenic neuropeptides. Both hypotheses are based on indirect supporting evidence. For instance, pharmacological inhibition or genetic ablation of hypothalamic CPT1 activity reduce food intake $[49,50]$. Conversely, increased hypothalamic CPT1 activity in the context of decreased malonyl-CoA levels after ghrelin treatment increases feeding [28]. Altogether, these data suggest that accumulation of fatty acyl-CoA is the mediator in the signalling pathway controlling feeding behaviour.

Despite the relevance of these data, they can appear contradictory in some way: FAS inhibitors are anorectic [39, 43, 44], implying that the activity of FAS (an anabolic enzyme) is usually involved in an orexigenic tone. On the other hand, CPT1 (a catabolic enzyme) is also orexigenic [49, 50]. The explanation for this apparent paradox is found in the malonyl-CoA levels and the integrated nature of metabolism, illustrated by the cooperative regulation of fatty acid synthesis and oxidation. Levels of malonyl-CoA play a key role in this system by acting not only as a substrate for FAS but also as a potent allosteric inhibitor of CPT1, the enzyme importing fatty acyl-CoA into the mitochondria for $\beta$-oxidation [30-32]. In summary, inhibition of FAS increases the cytoplasmatic malonyl-CoA content in hypothalamic neurons, which in turn inhibits CPT1 activity, leading to decreased feeding $[28,29,39,50]$.

\section{FAS: A Housekeeping Enzyme with Nucleus-Specific Regulation}

While FAS inhibitors displayed a marked anorectic action, it was unclear whether this effect affected the whole hy- pothalamus or was specific to selected hypothalamic nuclei or sets of neurons. Once more, a pharmacology-based approach answered this question. We have recently reported that tamoxifen (TMX), a widely used drug for the treatment of estrogen receptor-positive breast cancers, displays a very potent FAS inhibitory effect in the liver and in the hypothalamus $[39,51]$. Our data demonstrated that TMX-induced anorexia is associated with specific FAS inhibition, increased levels of malonyl-CoA in the hypothalamus and specific changes in CART and POMC in the ARC [39]. However, the most important finding of our study was that TMX inhibited FAS expression in a nucleus-specific pattern restricted to the VMH but not in other hypothalamic nuclei, such as ARC and PVH, or other brain areas, such as the cortex, the thalamus, and the hippocampus [39]. The physiological significance of these observations was further supported by the evidence of changes in hypothalamic FAS in response to fasting and refeeding. In spite of unchanged total levels of FAS mRNA and protein in the fasted state when analysing the entire brain or the whole hypothalamus in mammals $[28,36]$, our results showed that the nutritional status regulates hypothalamic FAS expression in a nucleus-specific manner, with FAS mRNA levels being downregulated by fasting and upregulated by refeeding, specifically in the VMH [27, 28, 39], which is the same nucleus where FAS was modulated after central or peripheral TMX administration. Overall, these data suggest an important role for FAS in the VMH, which was confirmed by the lean and hypophagic phenotype of FAS knockout mice (FASKO) in the VMH [40].

\section{Hypothalamic AMPK: A Master Cellular Sensor- Regulating Feeding Behaviour}

AMPK is a serine/threonine protein kinase composed of a catalytic subunit ( $\alpha 1$ or $\alpha 2)$ and 2 regulatory subunits ( $\beta 1$ or $\beta 2$ and $\gamma 1$ or $\gamma 2$ or $\gamma 3)$. AMPK is activated by phosphorylation on Thr172 of the $\alpha$ subunit, a process catalysed by LKB1 or $\mathrm{Ca}+2 /$ calmodulin-dependent protein kinase $\alpha$ or $\beta(\mathrm{CaMKK} \alpha$ or CaMKK $\beta)$ [30, 33, 52, 53]. Transforming growth factor- $\beta$ activated kinase (TAK1) also activates AMPK [54]. Current data also point out that protein phosphatase $2 \mathrm{C}(\mathrm{PP} 2 \mathrm{C})$ inactivates AMPK by dephosphorylation [55]. AMPK is allosterically activated by AMP, which also inhibits PP2C, increasing phosphorylation in Thr172. Whatever the mechanism, activated (phosphorylated) AMPK is a counter-regulatory response to avoid ATP depletion in many tissues to switch off ATP-consuming processes (such as fatty acid synthesis) whilst switching on catabolic processes that produce ATP (such as fatty acid $\beta$-oxidation) to restore the AMP:ATP ratio [30, 33, 52, 53].

Similarly to fatty acid metabolism enzymes, AMPK is expressed in several key hypothalamic nuclei, including ARC, LHA, PVH, and VMH [28, 38]. Regulation of hypothalamic 
Table 1. Regulation of hypothalamic AMPK function, ARC-derived neuropeptides, and feeding

\begin{tabular}{|c|c|c|c|c|c|c|}
\hline & AMPK function & AgRP & NPY & CART & POMC & Feeding \\
\hline \multicolumn{7}{|l|}{ Anorexigenic } \\
\hline$\alpha$-Lipoic acid & $\downarrow[59]$ & $-^{\mathrm{a}}$ & - & - & - & $\downarrow[59]$ \\
\hline Citrate & $\downarrow[60,78]$ & - & $\downarrow[60]$ & - & $\uparrow[60]$ & $\downarrow[60,78]$ \\
\hline CNTF & $\downarrow[62]$ & $\leftrightarrow[79]$ & $\downarrow[80]$ & $\uparrow[81]$ & $\uparrow[81]$ & $\downarrow[62,79-81]$ \\
\hline Feeding & $\downarrow[28,38]$ & $\downarrow[28,38,82]$ & $\downarrow[28,38,82-84]$ & $\uparrow[28,38,85]$ & $\uparrow[28,38,82,86]$ & $\downarrow[28,38,39,82-85]$ \\
\hline GLP-1 & $\downarrow[63]$ & $\downarrow[63]$ & $\downarrow[63]$ & $\uparrow[63]$ & $\uparrow[63]$ & $\downarrow[63,87]$ \\
\hline Glucose & $\begin{array}{l}\downarrow[38,56-58, \\
\quad 88,89]\end{array}$ & $\begin{array}{l}\downarrow[73,88] \\
\leftrightarrow[90]\end{array}$ & $\downarrow[88]$ & $\begin{array}{l}\downarrow[91] \\
\leftrightarrow[90]\end{array}$ & $\leftrightarrow[90]$ & $\downarrow[38,56-58,89]$ \\
\hline $\begin{array}{l}\text { High-protein } \\
\text { diet/amino acids }\end{array}$ & $\downarrow[92]$ & $\downarrow[93]$ & $\downarrow[92]$ & - & $\uparrow[92]$ & $\downarrow[92]$ \\
\hline Insulin & $\downarrow[38,94]$ & $\begin{array}{l}\downarrow[95,96] \\
\leftrightarrow[90]\end{array}$ & $\downarrow[19,90,97,98]$ & $\leftrightarrow[90]$ & $\uparrow[90,99,100]$ & $\downarrow[19,38,94,101,102]$ \\
\hline Leptin & $\downarrow[38]$ & $\downarrow[82,90,103]$ & $\downarrow[82,90,103]$ & $\uparrow[85,90]$ & $\uparrow[82,86,90,104]$ & $\begin{array}{l}\downarrow[20,28,38,82,85,86, \\
104-108]\end{array}$ \\
\hline MTII & $\downarrow[38]$ & $\downarrow[109-113]$ & $\downarrow[114-116]$ & - & $\uparrow[109-113]$ & $\downarrow[38,109-111,113-117]$ \\
\hline RSTN & $\uparrow[27]$ & $\downarrow[27]$ & $\downarrow[27]$ & $\uparrow[27]$ & $\leftrightarrow[27]$ & $\downarrow[27,118]$ \\
\hline \multicolumn{7}{|l|}{ Orexigenic } \\
\hline Adiponectin & $\uparrow[65,119]$ & - & $\uparrow[65]$ & - & $\downarrow[65]$ & $\uparrow[65]$ \\
\hline AgRP & $\uparrow[38]$ & $\downarrow[120]$ & $\leftrightarrow[121]$ & $\uparrow[120,121]$ & $\downarrow[109-112,122,123]$ & $\begin{array}{l}\uparrow[28,38,109,110, \\
110-112,120-123]\end{array}$ \\
\hline Cannabinoids & $\uparrow[64,71]$ & $\uparrow[124]$ & $\begin{array}{l}\uparrow[124] \\
\leftrightarrow[125]\end{array}$ & $\downarrow[125,126]$ & $\begin{array}{l}\downarrow[127-129] \\
\leftrightarrow[130]\end{array}$ & $\uparrow[64,71,124-126,131]$ \\
\hline Fasting & $\uparrow[28,38]$ & $\uparrow[28,38,82]$ & $\uparrow[28,38,82-84]$ & $\downarrow[28,38,85,91]$ & $\downarrow[28,38,82,86]$ & $\uparrow[28,38,39,82-86]$ \\
\hline Ghrelin & $\uparrow[28,61,64,71]$ & $\uparrow[24,25,28]$ & $\uparrow[24,28]$ & $\leftrightarrow[132,133]$ & $\begin{array}{l}\downarrow[133] \\
\leftrightarrow[134]\end{array}$ & $\begin{array}{l}\uparrow[22,24,25,28,61,64, \\
71,133,135]\end{array}$ \\
\hline Glucocorticoids & $\uparrow[66]$ & $\uparrow[66,136,137]$ & $\begin{array}{l}\uparrow[66] \\
\leftrightarrow[136,137]\end{array}$ & $\uparrow[136,138,139]$ & $\begin{array}{l}\downarrow[140] \\
\uparrow[136]\end{array}$ & $\uparrow[66,136-140]$ \\
\hline $\begin{array}{l}\text { Glucose } \\
\text { deprivation }\end{array}$ & $\uparrow[56-58,89]$ & $\begin{array}{l}\uparrow[73,141] \\
\leftrightarrow[142]\end{array}$ & $\uparrow[141,143-147]$ & $\begin{array}{l}\downarrow[148] \\
\leftrightarrow[147]\end{array}$ & $\begin{array}{l}\downarrow[148,149] \\
\leftrightarrow[147]\end{array}$ & $\begin{array}{l}\uparrow[56-58,89,141,143, \\
144,150]\end{array}$ \\
\hline $\begin{array}{l}\text { Thyroid } \\
\text { hormones }\end{array}$ & $\uparrow[67]$ & $\begin{array}{l}\uparrow[151] \\
\leftrightarrow[152]\end{array}$ & $\uparrow[67,151,153-156]$ & $\leftrightarrow[152]$ & $\downarrow[67,151]$ & $\uparrow[67,152,157,158]$ \\
\hline
\end{tabular}

AMPK is part of the adaptive changes observed during physiological regulation of feeding. Fasting stimulates hypothalamic AMPK, while refeeding inhibits it [27, 28, 33, 38]. Activation of AMPK in the hypothalamus (by using adenoviruses expressing constitutively active AMPK) is sufficient to increase food intake and body weight, whereas repression of hypothalamic AMPK activity (by using adenoviruses expressing dominant negative AMPK) induces anorexia [38]. Alterations in hypothalamic AMPK activity are associated with changes of neuropeptide expression. Overexpression of a dominant negative AMPK in the mediobasal hypothalamus represses mRNA expression of NPY and AgRP in the ARC, whilst conversely, overexpression of constitutively active AMPK increases the fasting-induced increase in expression of NPY and AgRP in the ARC and of MCH in the LHA [38].

Recent data have highlighted the key physiological importance of hypothalamic AMPK in the control of food intake. The effects of fasting and refeeding on hypothalamic AMPK can be linked to alterations in circulating nutrients, hormones, and ARC neuropeptides involved in energy homeostasis (table 1, fig. 2). Activation of AMPK in several hypothalamic nuclei such as $\mathrm{VMH}, \mathrm{ARC}$ and $\mathrm{PVH}$, appear to play a prominent role in hypoglycaemia sensing [56], mediating counter-regulatory responses $[57,58]$. In line with this, central administration of glucose suppresses AMPK activity in the hypothalamus [38]. $\alpha$-Lipoic acid, a cofactor of mitochondrial enzymes with antioxidant and anorectic properties, also inhibits AMPK activity in the hypothalamus [59]. Lastly, intracerebroventricular (ICV) administration of citrate elicits an anorexigenic response associated with inhibition of AMPK, activation of ACC, and subsequent increase in malonyl-CoA [60]. Anorectic hormones, such as leptin, insulin, glucagon-like peptide-1 (GLP-1), ciliary neurotrophic factor (CNTF), and melanocortin receptor agonists, including melanotan II (MTII), inhibit hypothalamic AMPK [38, 61-63]. On the other hand, orexigenic signals, such as cannabinoids, glucocorticoids, thyroid hormones, adiponectin, ghrelin, and AgRP, activate hypothalamic AMPK [28, 61, 64-67]. It is noteworthy that RSTN, despite its anorectic effect, activates hypothalamic AMPK [27]. So far, it is still unclear whether hypothalamic AMPK is involved in the anorexigenic/orexigenic properties of 
all those signals. We have recently reported that in the case of ghrelin, the orexigenic action is mediated via the AMPK-malonyl-CoA-CPT1 axis [28, 29]. In fact, pharmacologic or genetic inhibition of AMPK or CPT1 blunts ghrelin feeding-promoting effects [28]. In this sense, one interesting and unsolved question is whether specific changes in the AMPK-malonyl-CPT1 axis in the VMH are related to the classical ghrelin action on AgRP/ NPY neurons in the ARC [25]. Current data demonstrate that pharmacological or genetic manipulations of the AMPK-malonyl-CoA-CPT1 axis in the VMH induce marked changes in the expression of neuropeptides in the ARC ([68] and our unpublished observations). The molecular/neural mechanism underlying this effect is still unclear, but we speculate that glutamate neurons from the VMH to the ARC may play a critical role in this circuit $[69,70]$.

Besides its effects on the AMPK-malonyl-CoA-CPT1 axis, ghrelin exerts an interesting action on hypothalamic FAS, decreasing its expression specifically in the VMH, but not in other hypothalamic and extra-hypothalamic brain areas. We speculate that this effect prevents the decrease of hypothalamic malonyl-CoA in this nucleus (secondary to fasting-induced inactivation of ACC by AMPK) from reaching deleteriously low levels in the context of food deprivation, which would increase the level of $\beta$-oxidation and thus compromise neuronal viability [29]. Supporting this concept are our data showing that the reduction in FAS levels is not further decreased by prolonged fasting over a period of $48 \mathrm{~h}$ [39]. This suggests a tightly controlled low FAS threshold in hypothalamic neurons [29], which is mediated by a mechanism involving the transcriptional regulation of SREBP-1 by AMPK [28, 29].

Interestingly, the effect of ghrelin on AMPK has recently been linked to i) endocannabinoids, demonstrating that an intact cannabinoid signalling pathway is necessary for the orexigenic action of ghrelin and also for its stimulatory effects on AMPK [71] and ii) changes in hypothalamic mitochondrial reactive oxygen species (ROS) and respiration that are dependent on uncoupling protein 2 (UCP2) [68]. This effect is related to ghrelin-induced CPT1 activation [28, 29], which stimulates fatty acid $\beta$-oxidation, promoting the generation of ROS. Fatty acids and ROS increase UCP2-dependent uncoupling activity and UCP2 gene expression, which subsequently decreases ROS in a feedback manner, allowing appropriate ghrelin-induced gene transcription [68]. Further work is necessary to demonstrate whether this mechanism, besides ghrelin, is extensive to other peripheral signals modulating food intake.

The integrative role of hypothalamic AMPK in whole body homeostasis is demonstrated by the fact that nutrient- and hormone-induced alterations in hypothalamic AMPK activity correlate with changes of neuropeptide expression, mainly in the ARC, such as AgRP, NPY, CART, and POMC [27, 38, 60, 63, 66-68, 72-75] (table 1, fig. 2), but also in the LHA, such as melanin-concentrating hormone (MHC) [38], and in the $\mathrm{PVH}$, such as corticotrophin-releasing hormone $(\mathrm{CRH})$ [60]. The specific relevance of AMPK in the development of obesity is currently under study, with several data pointing out a major role for this enzyme. Diet-induced obesity (DIO) alters AMPK activity in both hypothalamus and skeletal muscle, with DIO mice displaying resistance to the action of leptin on AMPK [76]. These results suggest that flawed responses of AMPK to leptin might contribute to leptin resistance in obese states. AMPK $\alpha 2 \mathrm{KO}$ mice in POMC neurons (POMC $22 \mathrm{KO}$ ) fed on standard or high fat diet (HFD), show increased body weight and fat mass [74]. On the contrary, mice with selective ablation of AMPK $\alpha 2$ in $\mathrm{AgRP}(\mathrm{AgRP} \alpha 2 \mathrm{KO})$ neurons show an age-dependent lean phenotype [74]. CaMKK $\beta K O$ mice are protected against HFD-induced obesity, insulin resistance, and glucose intolerance, while exhibiting hypophagia and weight loss [77]. Finally, genetic ablation of AMPK in the VMH blunts the orexigenic effect of ghrelin [28]. Altogether these data indicate that hypothalamic AMPK is a suitable target for the treatment of obesity.

\section{Summary and Future Directions}

Complexity and redundancy are clear benefits to guarantee precise regulation of important homeostatic systems. Current anatomical, pharmacological, genetic, and physiological data unequivocally demonstrate that hypothalamic fatty acid metabolism plays a key role in the regulation of food intake. Our challenge for the years to come resides in trying to fully understand the molecular mechanism underlying these effects and subsequently open new avenues for the design and development of suitable drugs for the treatment of obesity and its comorbidities.

\section{Acknowledgements}

We thank Ricardo Lage and Luis Varela (University of Santiago de Compostela) and Dr. Johan Fern $\varnothing$ (University of Bergen, Norway) for their helpful comments and criticism. This work has been supported by grants from Xunta de Galicia (CD: PGIDIT06PXIB208063PR and ML: GRC2006/66), Fondo de Investigaciones Sanitarias (ML: PI061700), Ministerio de Educacion y Ciencia (CD: BFU2005 and ML: RyC-200700211), the European Union (CD: LSHM-CT-2003-503041: Diabesity; www.eurodiabesity.org), and Mútua Madrileña (CD and ML). CIBER de Fisiopatología de la Obesidad y Nutrición is an initiative of Instituto de Salud Carlos III, Spain.

\section{Disclosure}

The authors declared no conflict of interest. 


\section{References}

1 Frühbeck G, Gomez-Ambrosi J: Control of body weight: a physiologic and transgenic perspective Diabetologia 2003;46:143-172.

$\checkmark 2$ Medina-Gomez G, Vidal-Puig A: Gateway to the metabolic syndrome. Nat Med 2005;11:602-603.

3 Farooqi IS, O'Rahilly S: Monogenic obesity in humans. Annu Rev Med 2005;56:443-458.

$\checkmark 4$ Slawik M, Vidal-Puig AJ: Lipotoxicity, overnutrition and energy metabolism in aging. Ageing Res Rev 2006:5:144-164.

5 Hecherington A, Ranson S: The spontaneous activity and food intake of rats with hypothalamic lesions. Am J Physiol 1942;136:609-617.

6 Anand BK, Brobeck JR: Localization of a 'feeding center' in the hypothalamus of the rat. Proc Soc Exp Biol Med 1951;77:323-324.

7 Abizaid A, Gao Q, Horvath TL: Thoughts for food: brain mechanisms and peripheral energy balance. Neuron 2006;51:691-702.

8 Morton GJ, Cummings DE, Baskin DG, Barsh GS, Schwartz MW: Central nervous system control of food intake and body weight. Nature 2006;443:289_ 295.

9 López M, Tovar S, Vázquez MJ, Williams LM, Diéguez C: Peripheral tissue-brain interactions in the regulation of food intake. Proc Nutr Soc 2007;66: 131-155.

10 Coll AP, Farooqi IS, O'Rahilly S: The hormonal control of food intake. Cell 2007;129:251-262.

-11 Schwartz MW, Woods SC, Porte D Jr, Seeley RJ, Baskin DG: Central nervous system control of food intake. Nature 2000;404:661-671.

12 Roselli-Rehfuss L, Mountjoy KG, Robbins LS, Mortrud MT, Low MJ, Tatro JB, Entwistle ML, Simerly RB, Cone RD: Identification of a receptor for gamma melanotropin and other proopiomelanocortin peptides in the hypothalamus and limbic system. Proc Natl Acad Sci U S A 1993;90:8856-8860.

13 Mountjoy KG, Mortrud MT, Low MJ, Simerly $\mathrm{RB}$, Cone RD: Localization of the melanocortin4 receptor (MC4-R) in neuroendocrine and autonomic control circuits in the brain. Mol Endocrinol 1994;8:1298-1308.

14 Lindblom J, Schiöth HB, Larsson A, Wikberg JE, Bergström L: Autoradiographic discrimination of melanocortin receptors indicates that the MC3 subtype dominates in the medial rat brain. Brain Res 1998;810:161-171.

$\checkmark 15$ Elias CF, Saper CB, Maratos-Flier E, Tritos NA, Lee C, Kelly J, Tatro JB, Hoffman GE, Ollmann MM, Barsh GS, Sakurai T, Yanagisawa M, Elmquist JK: Chemically defined projections linking the mediobasal hypothalamus and the lateral hypothalamic area. J Comp Neurol 1998;402:442-459.

16 Haskell-Luevano C, Chen P, Li C, Chang K, Smith MS, Cameron JL, Cone RD: Characterization of the neuroanatomical distribution of agouti-related protein immunoreactivity in the rhesus monkey and the rat. Endocrinology 1999;140:1408-1415.

-17 Bagnol D, Lu XY, Kaelin CB, Day HE, Ollmann M, Gantz I, Akil H, Barsh GS, Watson SJ: Anatomy of an endogenous antagonist: relationship between Agouti-related protein and proopiomelanocortin in brain. J Neurosci 1999;19:1-7.

18 King BM: The rise, fall, and resurrection of the ventromedial hypothalamus in the regulation of feeding behavior and body weight. Physiol Behav 2006;87:221-244.

19 Schwartz MW, Sipols AJ, Marks JL, Sanacora G, White JD, Scheurink A, Kahn SE, Baskin DG, Woods SC, Figlewicz DP: Inhibition of hypothalamic neuropeptide Y gene expression by insulin. Endocrinology 1992;130:3608-3616.
Ahima RS, Prabakaran D, Mantzoros C, Qu D, Lowell B, Maratos-Flier E, Flier JS: Role of leptin in the neuroendocrine response to fasting. Nature 1996;382:250-252.

21 López M, Seoane L, García MC, Lago F, Casanueva FF, Senarís R, Diéguez C: Leptin regulation of prepro-orexin and orexin receptor mRNA levels in the hypothalamus. Biochem Biophys Res Commun 2000;269:41-45.

22 Tschöp M, Smiley DL, Heiman ML: Ghrelin induces adiposity in rodents. Nature 2000;407:908-913.

23 Obici S, Feng Z, Tan J, Liu L, Karkanias G, Rossetti L: Central melanocortin receptors regulate insulin action. J Clin Invest 2001;108:1079-1085.

24 Nakazato M, Murakami N, Date Y, Kojima M, Matsuo H, Kangawa K, Matsukura S: A role for ghrelin in the central regulation of feeding. Nature 2001;409:194-198.

25 Seoane LM, López M, Tovar S, Casanueva F, Señarís R, Diéguez C: Agouti-related peptide, neuropeptide $\mathrm{Y}$, and somatostatin-producing neurons are targets for ghrelin actions in the rat hypothalamus. Endocrinology 2003;144:544-551.

26 Qi Y, Takahashi N, Hileman SM, Patel HR, Berg AH, Pajvani UB, Scherer PE, Ahima RS: Adiponectin acts in the brain to decrease body weight. Nat Med 2004;10:524-529.

27 Vázquez MJ, González CR, Varela L, Lage R, Tovar S, Sangiao-Alvarellos S, Williams LM, VidalPuig A, Nogueiras R, López M, Diéguez C: Central resistin regulates hypothalamic and peripheral lipid metabolism in a nutritional-dependent fashion. Endocrinology 2008;149:4534-4543.

28 López M, Lage R, Saha AK, Pérez-Tilve D, Vàzquez MJ, Varela L, Sangiao-Alvarellos S, Tovar S, Raghay K, Rodríguez-Cuenca S, Deoliveira RM, Castañeda T, Datta R, Dong JZ, Culler M, Sleeman MW, Álvarez CV, Gallego R, Lelliott CJ, Carling D, Tschöp MH, Diéguez C, Vidal-Puig A: Hypothalamic fatty acid metabolism mediates the orexigenic action of ghrelin. Cell Metab 2008; 7:389-399.

29 López M, Saha AK, Diéguez C, Vidal-Puig A: The AMPK-malonyl-CoA-CPT1 axis in the control of hypothalamic neuronal function reply. Cell Metab 2008;8:176.

30 Ruderman NB, Saha AK, Kraegen EW: Minireview: malonyl CoA, AMP-activated protein kinase, and adiposity. Endocrinology 2003;144:5166-5171.

31 Dowell P, Hu Z, Lane MD: Monitoring energy balance: metabolites of fatty acid synthesis as hypothalamic sensors. Annu Rev Biochem 2005;74:515-534.

32 López M, Lelliott CJ, Vidal-Puig A: Hypothalamic fatty acid metabolism: a housekeeping pathway that regulates food intake. Bioessays 2007;29:248261.

33 Lage R, Diéguez C, Vidal-Puig A, López M: AMPK: a metabolic gauge regulating whole-body energy homeostasis. Trends Mol Med 2008;14:539549.

34 Zhou G, Myers R, Li Y, Chen Y, Shen X, FenykMelody J, Wu M, Ventre J, Doebber T, Fujii N, Musi N, Hirshman MF, Goodyear LJ, Moller DE: Role of AMP-activated protein kinase in mechanism of metformin action. J Clin Invest 2001;108: $1167-1174$

35 Ruderman NB, Saha AK, Vavvas D, Witters LA: Malonyl-CoA, fuel sensing, and insulin resistance. Am J Physiol 1999;276:E1-E18.
6 Kim EK, Miller I, Landree LE, Borisy-Rudin FF, Brown P, Tihan T, Townsend CA, Witters LA Moran TH, Kuhajda FP, Ronnett GV: Expression of FAS within hypothalamic neurons: a model for decreased food intake after C75 treatment. Am J Physiol Endocrinol Metab 2002;283:E867-E879.

37 Sorensen A, Travers MT, Vernon RG, Price NT, Barber MC: Localization of messenger RNAs encoding enzymes associated with malonyl-CoA metabolism in mouse brain. Brain Res Gene Expr Patterns 2002;1:167-173.

38 Minokoshi Y, Alquier T, Furukawa N, Kim YB, Lee A, Xue B, Mu J, Foufelle F, Ferre P, Birnbaum MJ, Stuck BJ, Kahn BB: AMP-kinase regulates food intake by responding to hormonal and nutrient signals in the hypothalamus. Nature 2004;428:569-574.

39 López M, Lelliott CJ, Tovar S, Kimber W, Gallego R, Virtue S, Blount M, Vázquez MJ, Finer N, Powles T, O'Rahilly S, Saha AK, Diéguez C, VidalPuig AJ: Tamoxifen-induced anorexia is associated with fatty acid synthase inhibition in the ventromedial nucleus of the hypothalamus and accumulation of malonyl-CoA. Diabetes 2006;55:1327-1336.

40 Chakravarthy MV, Zhu Y, López M, Yin L, Wozniak DW, Coleman T, Hu Z, Wolfgang M, VidalPuig A, Lane MD, Semenkovich CF: Brain fatty acid synthase activates PPAR-alpha to maintain energy homeostasis. J Clin Invest 2007;117:25392552.

41 Dai Y, Wolfgang MJ, Cha SH, Lane MD: Localization and effect of ectopic expression of CPT1c in CNS feeding centers. Biochem Biophys Res Commun 2007;359:469-474

42 Kuhajda FP, Jenner K, Wood FD, Hennigar RA, Jacobs LB, Dick JD, Pasternack GR: Fatty acid synthesis: a potential selective target for antineoplastic therapy. Proc Natl Acad Sci U S A 1994;91: 6379-6383.

43 Loftus TM, Jaworsky DE, Frehywot GL, Townsend CA, Ronnett GV, Lane MD, Kuhajda FP: Reduced food intake and body weight in mice treated with fatty acid synthase inhibitors. Science 2000;288:2379-2381.

$44 \mathrm{Hu}$ Z, Cha SH, Chohnan S, Lane MD: Hypothalamic malonyl-CoA as a mediator of feeding behavior. Proc Natl Acad Sci U S A 2003;100:1262412629.

45 Hu Z, Dai Y, Prentki M, Chohnan S, Lane MD: A role for hypothalamic malonyl-CoA in the control of food intake. J Biol Chem 2005;280:39681-39683.

46 He W, Lam TK, Obici S, Rossetti L: Molecular disruption of hypothalamic nutrient sensing induces obesity. Nat Neurosci 2006;9:227-233.

47 Gao S, Lane MD: Effect of the anorectic fatty acid synthase inhibitor $\mathrm{C} 75$ on neuronal activity in the hypothalamus and brainstem. Proc Natl Acad Sci U S A 2003;100:5628-5633.

48 Schujman GE, Paoletti L, Grossman AD, de Mendoza D: FapR, a bacterial transcription factor involved in global regulation of membrane lipid biosynthesis. Dev Cell 2003;4:663-672.

49 Obici S, Feng Z, Arduini A, Conti R, Rossetti L: Inhibition of hypothalamic carnitine palmitoyltransferase-1 decreases food intake and glucose production. Nat Med 2003;9:756-761.

50 Wolfgang MJ, Kurama T, Dai Y, Suwa A, Asaumi M, Matsumoto S, Cha SH, Shimokawa T, Lane MD: The brain-specific carnitine palmitoyltransferase-1c regulates energy homeostasis. Proc Natl Acad Sci U S A 2006;103:7282-7287. 
-51 Lelliott CJ, López M, Curtis RK, Parker N, Laudes M, Yeo G, Jimenez-Liñan M, Grosse J, Saha AK, Wiggins D, Hauton D, Brand MD, O'Rahilly S, Griffin JL, Gibbons GF, Vidal-Puig A: Transcript and metabolite analysis of the effects of tamoxifen in rat liver reveals inhibition of fatty acid synthesis in the presence of hepatic steatosis. FASEB J 2005;19:1108-1119.

\52 Kahn BB, Alquier T, Carling D, Hardie DG: AMPactivated protein kinase: ancient energy gauge provides clues to modern understanding of metabolism. Cell Metab 2005;1:15-25.

53 Carling D, Sanders MJ, Woods A: The regulation of AMP-activated protein kinase by upstream kinases. Int J Obes (Lond) 2008;32(suppl 4):S55-S59.

54 Xie M, Zhang D, Dyck JR, Li Y, Zhang H, Morishima M, Mann DL, Taffet GE, Baldini A, Khoury DS, Schneider MD: A pivotal role for endogenous TGF-beta-activated kinase-1 in the LKB1/AMPactivated protein kinase energy-sensor pathway. Proc Natl Acad Sci U S A 2006;103:17378-17383.

55 Steinberg GR, Michell BJ, van Denderen BJ, Watt MJ, Carey AL, Fam BC, Andrikopoulos S, Proietto J, Gorgun CZ, Carling D, Hotamisligil GS, Febbraio MA, Kay TW, Kemp BE: Tumor necrosis factor alpha-induced skeletal muscle insulin resistance involves suppression of AMP-kinase signaling. Cell Metab 2006;4:465-474.

56 McCrimmon RJ, Fan X, Ding Y, Zhu W, Jacob RJ Sherwin RS: Potential role for AMP-activated protein kinase in hypoglycemia sensing in the ventromedial hypothalamus. Diabetes 2004;53:1953-1958.

57 Han SM, Namkoong C, Jang PG, Park IS, Hong SW, Katakami H, Chun S, Kim SW, Park JY, Lee KU, Kim MS: Hypothalamic AMP-activated protein kinase mediates counter-regulatory responses to hypoglycaemia in rats. Diabetologia 2005;48:2170-2178.

58 McCrimmon RJ, Fan X, Cheng H, McNay E, Chan O, Shaw M, Ding Y, Zhu W, Sherwin RS: Activation of AMP-activated protein kinase within the ventromedial hypothalamus amplifies counterregulatory hormone responses in rats with defective counterregulation. Diabetes 2006;55:1755-1760.

59 Kim MS, Park JY, Namkoong C, Jang PG, Ryu JW, Song HS, Yun JY, Namgoong IS, Ha J, Park IS, Lee IK, Viollet B, Youn JH, Lee HK, Lee KU: Anti-obesity effects of alpha-lipoic acid mediated by suppression of hypothalamic AMP-activated protein kinase. Nat Med 2004;10:727-733.

60 Stoppa GR, Cesquini M, Roman EA, Prada PO, Torsoni AS, Romanatto T, Saad MJ, Velloso LA, Torsoni MA: Intracerebroventricular injection of citrate inhibits hypothalamic AMPK and modulates feeding behavior and peripheral insulin signaling. J Endocrinol 2008;198:157-168.

61 Andersson U, Filipsson K, Abbott CR, Woods A, Smith K, Bloom SR, Carling D, Small CJ: AMPactivated protein kinase plays a role in the control of food intake. J Biol Chem 2004;279:12005-12008.

62 Steinberg GR, Watt MJ, Fam BC, Proietto J, Andrikopoulos S, Allen AM, Febbraio MA, Kemp BE: Ciliary neurotrophic factor suppresses hypothalamic AMP-kinase signaling in leptin-resistan obese mice. Endocrinology 2006;147:3906-3914.

63 Seo S, Ju S, Chung H, Lee D, Park S: Acute effects of glucagon-like peptide-1 on hypothalamic neuropeptide and AMP activated kinase expression in fasted rats. Endocr J 2008;55:867-874.

64 Kola B, Hubina E, Tucci SA, Kirkham TC, Garcia EA, Mitchell SE, Williams LM, Hawley SA, Hardie DG, Grossman AB, Korbonits M: Cannabinoids and ghrelin have both central and peripheral metabolic and cardiac effects via AMP-activated protein kinase. J Biol Chem 2005;280:25196-25201.
5 Kubota N, Yano W, Kubota T, Yamauchi T, Itoh S, Kumagai H, Kozono H, Takamoto I, Okamoto S, Shiuchi T, Suzuki R, Satoh H, Tsuchida A, Moroi M, Sugi K, Noda T, Ebinuma H, Ueta Y, Kondo T, Araki E, Ezaki O, Nagai R, Tobe K, Terauchi Y, Ueki K, Minokoshi Y, Kadowaki T: Adiponectin stimulates AMP-activated protein kinase in the hypothalamus and increases food intake. Cell Metab 2007;6:55-68.

66 Shimizu H, Arima H, Watanabe M, Goto M, Banno R, Sato I, Ozaki N, Nagasaki H, Oiso Y: Glucocorticoids increase neuropeptide $\mathrm{Y}$ and agouti-related peptide gene expression via AMP-activated protein kinase signaling in the arcuate nucleus of rats. Endocrinology 2008;149:4544-4553.

67 Ishii S, Kamegai J, Tamura H, Shimizu T, Sugihara H, Oikawa S: Triiodothyronine (T3) stimulates food intake via enhanced hypothalamic AMP-activated kinase activity. Regul Pept 2008;151:164169.

68 Andrews ZB, Liu ZW, Wallingford N, Erion DM, Borok E, Friedman JM, Tschöp MH, Shanabrough M, Cline G, Shulman GI, Coppola A, Gao XB, Horvath TL, Diano S: UCP2 mediates ghrelin's action on NPY/AgRP neurons by lowering free radicals. Nature 2008;454:846-851.

69 Sternson SM, Shepherd GM, Friedman JM: Topographic mapping of $\mathrm{VMH} \rightarrow$ arcuate nucleus microcircuits and their reorganization by fasting. Nat Neurosci 2005;8:1356-1363.

70 Tong Q, Ye C, McCrimmon RJ, Dhillon H, Choi B, Kramer MD, Yu J, Yang Z, Christiansen LM, Lee CE, Choi CS, Zigman JM, Shulman GI, Sherwin RS, Elmquist JK, Lowell BB: Synaptic glutamate release by ventromedial hypothalamic neurons is part of the neurocircuitry that prevents hypoglycemia. Cell Metab 2007;5:383-393.

71 Kola B, Farkas I, Christ-Crain M, Wittmann G, Lolli F, Amin F, Harvey-White J, Liposits Z, Kunos G, Grossman AB, Fekete C, Korbonits M: The orexigenic effect of ghrelin is mediated through central activation of the endogenous cannabinoid system. PLoS ONE 2008;3:e1797.

72 Kim EK, Miller I, Aja S, Landree LE, Pinn M, McFadden J, Kuhajda FP, Moran TH, Ronnett GV: C75, a fatty acid synthase inhibitor, reduces food intake via hypothalamic AMP-activated protein kinase. J Biol Chem 2004;279:19970-19976.

73 Lee K, Li B, Xi X, Suh Y, Martin RJ: Role of neuronal energy status in the regulation of adenosine 5 '-monophosphate-activated protein kinase, orexigenic neuropeptides expression, and feeding behavior. Endocrinology 2005;146:3-10.

74 Claret M, Smith MA, Batterham RL, Selman C, Choudhury AI, Fryer LG, Clements M, Al Qassab H, Heffron H, Xu AW, Speakman JR, Barsh GS, Viollet B, Vaulont S, Ashford ML, Carling D, Withers DJ: AMPK is essential for energy homeostasis regulation and glucose sensing by POMC and AgRP neurons. J Clin Invest 2007;117:2325-2336.

75 Mountjoy PD, Bailey SJ, Rutter GA: Inhibition by glucose or leptin of hypothalamic neurons expressing neuropeptide $\mathrm{Y}$ requires changes in AMPactivated protein kinase activity. Diabetologia 2007;50:168-177.

76 Martin TL, Alquier T, Asakura K, Furukawa N, Preitner F, Kahn BB: Diet-induced obesity alters AMP kinase activity in hypothalamus and skeletal muscle. J Biol Chem 2006;281:18933-18941.

77 Anderson KA, Ribar TJ, Lin F, Noeldner PK, Green MF, Muehlbauer MJ, Witters LA, Kemp BE, Means AR: Hypothalamic CaMKK2 contributes to the regulation of energy balance. Cell Metab 2008;7:377-388.
8 Cesquini M, Stoppa GR, Prada PO, Torsoni AS, Romanatto T, Souza A, Saad MJ, Velloso LA, Torson MA: Citrate diminishes hypothalamic acetyl-CoA carboxylase phosphorylation and modulates satiety signals and hepatic mechanisms involved in glucose homeostasis in rats. Life Sci 2008;82:1262-1271.

79 Ziotopoulou M, Erani DM, Hileman SM, Bjorbaek C, Mantzoros CS: Unlike leptin, ciliary neurotrophic factor does not reverse the starvation-induced changes of serum corticosterone and hypothalamic neuropeptide levels but induces expression of hypothalamic inhibitors of leptin signaling. Diabetes 2000;49:1890-1896.

80 Xu B, Dube MG, Kalra PS, Farmerie WG, Kaibara A, Moldawer LL, Martin D, Kalra SP: Anorectic effects of the cytokine, ciliary neurotropic factor, are mediated by hypothalamic neuropeptide Y: comparison with leptin. Endocrinology 1998;139: 466-473.

81 Ambati S, Duan J, Duff E, Choi YH, Hartzell DL, Della-Fera MA, Baile CA: Gene expression in arcuate nucleus-median eminence of rats treated with leptin or ciliary neurotrophic factor. Biofactors 2007;31:133-144.

82 Swart I, Jahng JW, Overton JM, Houpt TA: Hypothalamic NPY, AGRP, and POMC mRNA responses to leptin and refeeding in mice. Am J Physiol Regul Integr Comp Physiol 2002;283: R1020-R1026.

83 Sanacora G, Kershaw M, Finkelstein JA, White JD: Increased hypothalamic content of preproneuropeptide $\mathrm{Y}$ messenger ribonucleic acid in genetically obese Zucker rats and its regulation by food deprivation. Endocrinology 1990;127:730-737.

84 Kalra SP, Dube MG, Sahu A, Phelps CP, Kalra PS: Neuropeptide Y secretion increases in the paraventricular nucleus in association with increased appetite for food. Proc Natl Acad Sci U S A 1991;88: 10931-10935.

85 Kristensen P, Judge ME, Thim L, Ribel U, Christjansen KN, Wulff BS, Clausen JT, Jensen PB, Madsen OD, Vrang N, Larsen PJ, Hastrup S: Hypothalamic CART is a new anorectic peptide regulated by leptin. Nature 1998;393:72-76.

86 Schwartz MW, Seeley RJ, Woods SC, Weigle DS, Campfield LA, Burn P, Baskin DG: Leptin increases hypothalamic pro-opiomelanocortin mRNA expression in the rostral arcuate nucleus. Diabetes 1997;46:2119-2123.

87 Scrocchi LA, Brown TJ, MaClusky N, Brubaker PL, Auerbach AB, Joyner AL, Drucker DJ: Glucose intolerance but normal satiety in mice with a null mutation in the glucagon-like peptide 1 receptor gene. Nat Med 1996;2:1254-1258.

88 Chang GQ, Karatayev O, Davydova Z, Wortley K, Leibowitz SF: Glucose injection reduces neuropeptide $\mathrm{Y}$ and agouti-related protein expression in the arcuate nucleus: a possible physiological role in eating behavior. Brain Res Mol Brain Res 2005;135:69-80.

89 Wolfgang MJ, Cha SH, Sidhaye A, Chohnan S, Cline G, Shulman GI, Lane MD: Regulation of hypothalamic malonyl-CoA by central glucose and leptin. Proc Natl Acad Sci U S A 2007;104:19285-19290.

90 Fekete C, Singru PS, Sanchez E, Sarkar S, Christoffolete MA, Riberio RS, Rand WM, Emerson CH, Bianco AC, Lechan RM: Differential effects of central leptin, insulin, or glucose administration during fasting on the hypothalamic-pituitary-thyroid axis and feeding-related neurons in the arcuate nucleus. Endocrinology 2006;147:520-529.

$91 \mathrm{Li}$ HY, Hwang HW, Hu YH: Functional characterizations of cocaine- and amphetamine-regulated transcript mRNA expression in rat hypothalamus. Neurosci Lett 2002;323:203-206. 
92 Ropelle ER, Pauli JR, Fernandes MF, Rocco SA, Marin RM, Morari J, Souza KK, Dias MM, Gomes-Marcondes MC, Gontijo JA, Franchini KG, Velloso LA, Saad MJ, Carvalheira JB: A central role for neuronal AMP-activated protein kinase (AMPK) and mammalian target of rapamycin (mTOR) in high-protein diet-induced weight loss. Diabetes 2008;57:594-605.

93 Morrison CD, Xi X, White CL, Ye J, Martin RJ Amino acids inhibit Agrp gene expression via an mTOR-dependent mechanism. Am J Physiol Endocrinol Metab 2007;293:E165-E171.

94 Namkoong C, Kim MS, Jang PG, Han SM, Park HS, Koh EH, Lee WJ, Kim JY, Park IS, Park JY, Lee KU: Enhanced hypothalamic AMP-activated protein kinase activity contributes to hyperphagia in diabetic rats. Diabetes 2005;54:63-68.

-95 Dunbar J, Lapanowski K, Barnes M, Rafols J: Hypothalamic agouti-related protein immunoreactivity in food-restricted, obese, and insulintreated animals: evidence for glia cell localization. Exp Neurol 2005;191:184-192.

$\checkmark 6$ Konner AC, Janoschek R, Plum L, Jordan SD, Rother E, Ma X, Xu C, Enriori P, Hampel B, Barsh GS, Kahn CR, Cowley MA, Ashcroft FM, Bruning JC: Insulin action in AgRP-expressing neurons is required for suppression of hepatic glucose production. Cell Metab 2007;5:438-449.

97 Schwartz MW, Marks JL, Sipols AJ, Baskin DG, Woods SC, Kahn SE, Porte D Jr: Central insulin administration reduces neuropeptide $\mathrm{Y}$ mRNA expression in the arcuate nucleus of food-deprived lean $(\mathrm{Fa} / \mathrm{Fa})$ but not obese (fa/fa) Zucker rats. Endocrinology 1991;128:2645-2647.

98 Sipols AJ, Baskin DG, Schwartz MW: Effect of intracerebroventricular insulin infusion on diabetic hyperphagia and hypothalamic neuropeptide gene expression. Diabetes 1995;44:147-151.

99 Kim EM, Grace MK, Welch CC, Billington CJ, Levine AS: STZ-induced diabetes decreases and insulin normalizes POMC mRNA in arcuate nucleus and pituitary in rats. Am J Physiol 1999;276: R1320-R1326.

100 Benoit SC, Air EL, Coolen LM, Strauss R, Jackman A, Clegg DJ, Seeley RJ, Woods SC: The catabolic action of insulin in the brain is mediated by melanocortins. J Neurosci 2002;22:9048-9052.

- 101 Woods SC, Lotter EC, McKay LD, Porte D Jr Chronic intracerebroventricular infusion of insulin reduces food intake and body weight of baboons. Nature 1979;282:503-505.

102 Ikeda H, West DB, Pustek JJ, Figlewicz DP, Greenwood MR, Porte D Jr, Woods SC: Intraventricular insulin reduces food intake and body weight of lean but not obese Zucker rats. Appetite 1986;7:381-386.

103 Ahima RS, Flier JS: Leptin. Annu Rev Physiol 2000;62:413-437.

104 Elias CF, Aschkenasi C, Lee C, Kelly J, Ahima RS, Bjorbaek C, Flier JS, Saper CB, Elmquist JK: Leptin differentially regulates NPY and POMC neurons projecting to the lateral hypothalamic area. Neuron 1999;23:775-786.

-105 Stephens TW, Basinski M, Bristow PK, BueValleskey JM, Burgett SG, Craft L, Hale J, Hoffmann J, Hsiung HM, Kriauciunas A: The role of neuropeptide $\mathrm{Y}$ in the antiobesity action of the obese gene product. Nature 1995;377:530-532.

-106 Halaas JL, Gajiwala KS, Maffei M, Cohen SL, Chait BT, Rabinowitz D, Lallone RL, Burley SK, Friedman JM: Weight-reducing effects of the plasma protein encoded by the obese gene. Science 1995;269:543-546.
107 Hahn TM, Breininger JF, Baskin DG, Schwartz MW: Coexpression of Agrp and NPY in fastingactivated hypothalamic neurons. Nat Neurosci 1998; 1:271-272.

108 Ahima RS: Leptin and the neuroendocrinology of fasting. Front Horm Res 2000;26:42-56.

109 Marsh DJ, Hollopeter G, Huszar D, Laufer R, Yagaloff KA, Fisher SL, Burn P, Palmiter RD: Response of melanocortin-4 receptor-deficient mice to anorectic and orexigenic peptides. Nat Genet 1999;21:119-122.

110 Hagan MM, Rushing PA, Pritchard LM, Schwartz MW, Strack AM, Van Der Ploeg LH, Woods SC, Seeley RJ: Long-term orexigenic effects of AgRP-(83-132) involve mechanisms other than melanocortin receptor blockade. Am J Physiol Regul Integr Comp Physiol 2000;279:R47-R52.

111 Haskell-Luevano C, Monck EK: Agouti-related protein functions as an inverse agonist at a constitutively active brain melanocortin-4 receptor. Regul Pept 2001;99:1-7.

-112 Haskell-Luevano C, Cone RD, Monck EK, Wan YP: Structure activity studies of the melanocortin4 receptor by in vitro mutagenesis: identification of agouti-related protein (AGRP), melanocortin agonist and synthetic peptide antagonist interaction determinants. Biochemistry 2001;40:6164-6179.

113 Trivedi P, Jiang M, Tamvakopoulos CC, Shen X, Yu H, Mock S, Fenyk-Melody J, Van Der Ploeg LH, Guan XM: Exploring the site of anorectic action of peripherally administered synthetic melanocortin peptide MT-II in rats. Brain Res 2003;977:221-230.

114 Fan W, Boston BA, Kesterson RA, Hruby VJ, Cone RD: Role of melanocortinergic neurons in feeding and the agouti obesity syndrome. Nature 1997;385:165-168.

115 Murphy B, Nunes CN, Ronan JJ, Harper CM, Beall MJ, Hanaway M, Fairhurst AM, Van Der Ploeg LH, MacIntyre DE, Mellin TN: Melanocortin mediated inhibition of feeding behavior in rats. Neuropeptides 1998;32:491-497.

116 Raposinho PD, White RB, Aubert ML: The melanocortin agonist Melanotan-II reduces the orexigenic and adipogenic effects of neuropeptide Y (NPY) but does not affect the NPY-driven suppressive effects on the gonadotropic and somatotropic axes in the male rat. J Neuroendocrinol 2003;15:173-181.

117 Nogueiras R, Wiedmer P, Perez-Tilve D, VeyratDurebex C, Keogh JM, Sutton GM, Pfluger PT, Castañeda TR, Neschen S, Hofmann SM, Howles PN, Morgan DA, Benoit SC, Szanto I, Schrott B, Schurmann A, Joost HG, Hammond C, Hui DY, Woods SC, Rahmouni K, Butler AA, Farooqi IS, O'Rahilly S, Rohner-Jeanrenaud F, Tschöp MH: The central melanocortin system directly controls peripheral lipid metabolism. J Clin Invest 2007;117: 3475-3488.

118 Tovar S, Nogueiras R, Tung LY, Castaneda TR, Vázquez MJ, Morris A, Williams LM, Dickson SL, Diéguez C: Central administration of resistin promotes short-term satiety in rats. Eur J Endocrinol 2005;153:R1-R5.

119 Guillod-Maximin E, Roy AF, Vacher CM, Aubourg A, Bailleux V, Lorsignol A, Penicaud L, Parquet M, Taouis M: Adiponectin receptors are expressed in hypothalamus and colocalized with proopiomelanocortin and neuropeptide $\mathrm{Y}$ in rodent arcuate neurons. J Endocrinol 2009;200:93-105.

120 Korner J, Wissig S, Kim A, Conwell IM, Wardlaw SL: Effects of agouti-related protein on metabolism and hypothalamic neuropeptide gene expression. J Neuroendocrinol 2003;15:1116-1121.
121 Zheng H, Corkern MM, Crousillac SM, Patterson LM, Phifer CB, Berthoud HR: Neurochemical phenotype of hypothalamic neurons showing Fos expression $23 \mathrm{~h}$ after intracranial AgRP. Am J Physiol Regul Integr Comp Physiol 2002;282: R1773-R1781.

122 Ollmann MM, Wilson BD, Yang YK, Kerns JA, Chen Y, Gantz I, Barsh GS: Antagonism of central melanocortin receptors in vitro and in vivo by agouti-related protein. Science 1997;278:135-138.

123 Wilson BD, Bagnol D, Kaelin CB, Ollmann MM, Gantz I, Watson SJ, Barsh GS: Physiological and anatomical circuitry between Agouti-related protein and leptin signaling. Endocrinology 1999; 140:2387-2397.

124 Gamber KM, Macarthur H, Westfall TC: Cannabinoids augment the release of neuropeptide $\mathrm{Y}$ in the rat hypothalamus. Neuropharmacology 2005; 49:646-652.

125 Cota D, Marsicano G, Tschöp M, Grubler Y, Flachskamm C, Schubert M, Auer D, Yassouridis A, Thöne-Reineke C, Ortmann S, Tomassoni F, Cervino C, Nisoli E, Linthorst AC, Pasquali R, Lutz B, Stalla GK, Pagotto U: The endogenous cannabinoid system affects energy balance via central orexigenic drive and peripheral lipogenesis. J Clin Invest 2003;112:423-431.

126 Osei-Hyiaman D, Depetrillo M, Harvey-White J, Bannon AW, Cravatt BF, Kuhar MJ, Mackie K, Palkovits M, Kunos G: Cocaine- and amphetamine-related transcript is involved in the orexigenic effect of endogenous anandamide. Neuroendocrinology 2005;81:273-282.

127 Verty AN, McFarlane JR, McGregor IS, Mallet PE: Evidence for an interaction between $\mathrm{CB} 1$ cannabinoid and melanocortin MCR-4 receptors in regulating food intake. Endocrinology 2004;145: 3224-3231.

128 Hentges ST, Low MJ, Williams JT: Differential regulation of synaptic inputs by constitutively released endocannabinoids and exogenous cannabinoids. J Neurosci 2005;25:9746-9751.

129 Nguyen QH, Wagner EJ: Estrogen differentially modulates the cannabinoid-induced presynaptic inhibition of amino acid neurotransmission in proopiomelanocortin neurons of the arcuate nucleus. Neuroendocrinology 2006;84:123-137.

130 Sinnayah P, Jobst EE, Rathner JA, Caldera-Siu AD, Tonelli-Lemos L, Eusterbrock AJ, Enriori PJ, Pothos EN, Grove KL, Cowley MA: Feeding induced by cannabinoids is mediated independently of the melanocortin system. PLoS ONE 2008; 3:e2202.

131 Nogueiras R, Veyrat-Durebex C, Suchanek PM, Klein M, Tschöp J, Caldwell C, Woods SC, Wittmann G, Watanabe M, Liposits Z, Fekete C, Reizes O, Rohner-Jeanrenaud F, Tschöp MH: Peripheral, but not central, CB1 antagonism provides food intake-independent metabolic benefits in diet-induced obese rats. Diabetes 2008;57:29772991.

132 Wren AM, Small CJ, Ward HL, Murphy KG, Dakin CL, Taheri S, Kennedy AR, Roberts GH, Morgan DG, Ghatei MA, Bloom SR: The novel hypothalamic peptide ghrelin stimulates food intake and growth hormone secretion. Endocrinology 2000;141:4325-4328.

$133 \mathrm{Hu}$ Z, Cha SH, van Haasteren G, Wang J, Lane MD: Effect of centrally administered C75, a fatty acid synthase inhibitor, on ghrelin secretion and its downstream effects. Proc Natl Acad Sci U S A 2005;102:3972-3977. 
134 Kamegai J, Tamura H, Shimizu T, Ishii S, Sugihara H, Wakabayashi I: Central effect of ghrelin, an endogenous growth hormone secretagogue, on hypothalamic peptide gene expression. Endocrinology 2000;141:4797-4800.

135 Wren AM, Small CJ, Abbott CR, Dhillo WS, Seal LJ, Cohen MA, Batterham RL, Taheri S, Stanley SA, Ghatei MA, Bloom SR: Ghrelin causes hyperphagia and obesity in rats. Diabetes 2001;50:2540-2547.

136 Savontaus E, Conwell IM, Wardlaw SL: Effects of adrenalectomy on AGRP, POMC, NPY and CART gene expression in the basal hypothalamus of fed and fasted rats. Brain Res 2002;958:130-138.

137 Coll AP, Challis BG, López M, Piper S, Yeo GS, O'Rahilly S: Proopiomelanocortin-deficient mice are hypersensitive to the adverse metabolic effects of glucocorticoids. Diabetes 2005;54:2269-2276.

138 Vrang N, Larsen PJ, Tang-Christensen M, Larsen LK, Kristensen P: Hypothalamic cocaine-amphetamine regulated transcript (CART) is regulated by glucocorticoids. Brain Res 2003;965:45-50.

139 Germano CM, de Castro M, Rorato R, Laguna MT, Antunes-Rodrigues J, Elias CF, Elias LL: Time course effects of adrenalectomy and food intake on cocaine- and amphetamine-regulated transcript expression in the hypothalamus. Brain Res 2007;1166:55-64.

140 Arvaniti K, Huang Q, Richard D: Effects of leptin and corticosterone on the expression of corticotropin-releasing hormone, agouti-related protein, and proopiomelanocortin in the brain of ob/ob mouse. Neuroendocrinology 2001;73:227-236.

- 141 Hidaka S, Yoshimatsu H, Kondou S, Oka K, Tsuruta Y, Sakino H, Itateyama E, Noguchi H, Himeno K, Okamoto K, Teshima Y, Okeda T, Sakata T: Hypoleptinemia, but not hypoinsulinemia, induces hyperphagia in streptozotocin-induced diabetic rats. J Neurochem 2001;77:993-1000.

142 Luquet S, Phillips CT, Palmiter RD: NPY/AgRP neurons are not essential for feeding responses to glucoprivation. Peptides 2007;28:214-225.

143 Sindelar DK, Mystkowski P, Marsh DJ, Palmiter RD, Schwartz MW: Attenuation of diabetic hyperphagia in neuropeptide Y-deficient mice. Diabetes 2002;51:778-783.
144 Sindelar DK, Ste ML, Miura GI, Palmiter RD, McMinn JE, Morton GJ, Schwartz MW: Neuropeptide $\mathrm{Y}$ is required for hyperphagic feeding in response to neuroglucopenia. Endocrinology 2004;145:3363-3368.

145 Tkacs NC, Levin BE: Obesity-prone rats have preexisting defects in their counterregulatory response to insulin-induced hypoglycemia. Am J Physiol Regul Integr Comp Physiol 2004;287: R1110-R1115.

146 Briski KP, Parihar M: Effects of orchidectomy on adaptation of arcuate neuropeptide Y, proopiomelanocortin, and cocaine- and amphetaminerelated transcript gene profiles to recurring insulininduced hypoglycemia in the male rat. Neuropeptides 2008;42:585-591.

147 Watanabe M, Arima H, Fukushima K, Goto M, Shimizu H, Hayashi M, Banno R, Sato I, Ozaki N, Nagasaki H, Oiso Y: Direct and indirect modulation of neuropeptide $\mathrm{Y}$ gene expression in response to hypoglycemia in rat arcuate nucleus. FEBS Lett 2008;582:3632-3638

148 Nedungadi TP, Briski KP: Effects of estradiol on acute and recurrent insulin-induced hypoglycemia-associated patterns of arcuate neuropeptide Y, proopiomelanocortin, and cocaine- and amphetamine-related transcript gene expression in the ovariectomized rat. Neuroendocrinology 2007:86:270-276.

149 Tkacs NC, Dunn-Meynell AA, Levin BE: Presumed apoptosis and reduced arcuate nucleus neuropeptide $\mathrm{Y}$ and pro-opiomelanocortin mRNA in noncoma hypoglycemia. Diabetes 2000;49:820-826.

150 Dryden S, Pickavance L, Henderson L, Williams G: Hyperphagia induced by hypoglycemia in rats is independent of leptin and hypothalamic neuropeptide Y (NPY). Peptides 1998;19:1549-1555.

151 Coppola A, Liu ZW, Andrews ZB, Paradis E, Roy MC, Friedman JM, Ricquier D, Richard D, Horvath TL, Gao XB, Diano S: A central thermogenic-like mechanism in feeding regulation: an interplay between arcuate nucleus T3 and UCP2. Cell Metab 2007;5:21-33.
152 López M, Seoane LM, Tovar S, Señarís R, Diéguez C: Thyroid status regulates cocaine and amphetamine-regulated transcript but not agoutirelated peptide mRNA levels in the rat hypothalamus. Neuroreport;13:1775-1779.

153 Ishii S, Kamegai J, Tamura H, Shimizu T, Sugihara H, Oikawa S: Hypothalamic neuropeptide Y/Y1 receptor pathway activated by a reduction in circulating leptin, but not by an increase in circulating ghrelin, contributes to hyperphagia associated with triiodothyronine-induced thyrotoxicosis. Neuroendocrinology 2003;78:321-330.

154 Yilmazer-Hanke DM, Hantsch M, Hanke J, Schulz C, Faber-Zuschratter H, Schwegler H: Neonatal thyroxine treatment: changes in the number of corticotropin-releasing-factor (CRF) and neuropeptide Y (NPY) containing neurons and density of tyrosine hydroxylase positive fibers (TH) in the amygdala correlate with anxiety-related behavior of wistar rats. Neuroscience 2004:124:283-297.

155 Petervari E, Balasko M, Jech-Mihalffy A, Szekely M: Hyperphagia of hyperthyroidism: is neuropeptide Y involved? Regul Pept 2005;131:103-110.

156 Petervari E, Balasko M, Uzsoki B, Szekely M: Effects of neuropeptide $\mathrm{Y}$ antagonists on food intake in rats: differences with cold-adaptation. Peptides 2006;27:150-156.

157 López M, Seoane L, Señarís R, Diéguez C: Prepro-orexin mRNA levels in the rat hypothalamus, and orexin receptors mRNA levels in the rat hypothalamus and adrenal gland are not influenced by the thyroid status. Neurosci Lett 2001;300:171175.

158 Kong WM, Martin NM, Smith KL, Gardiner JV, Connoley IP, Stephens DA, Dhillo WS, Ghatei MA, Small CJ, Bloom SR: Tri-iodothyronine stimulates food intake via the hypothalamic ventromedial nucleus independent of changes in energy expenditure. Endocrinology 2004;145:52525258. 